\title{
The Etiology and Clinical Follow-up of Patients with Acute Viral Hepatitis in an Adult Population: A Prospective Multi- center Study
}

\author{
Erișkin Popülasyonda Akut Viral Hepatitli Hastaların Etiyolojisi ve Klinik Takibi: Prospektif \\ Çok Merkezli Bir Çalıșma
}

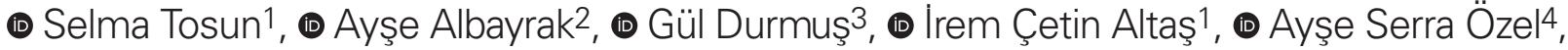 \\ (1) Necla Tülek5, (1) Ayten Kadanalı4, (1) Serpil Erol6, (1) Arzu Altunçekiç Yıldırım77, (1) Nurgül Ceran 6, \\ (1) Özgür Dağli³, (D) Ali llgın Olut
}

\begin{abstract}
1 University of Health Sciences Turkey, Izmir Bozyaka Training and Research Hospital, Clinic of Infectious Diseases and Clinical Microbiology, Izmir, Turkey ${ }^{2}$ Atatürk University Faculty of Medicine, Department of Infectious Diseases and Clinical Microbiology, Erzurum, Turkey

3 University of Health Sciences Turkey, Bursa Training and Research Hospital, Clinic of Infectious Diseases and Clinical Microbiology, Bursa, Turkey 4 University of Health Sciences Turkey, Ümraniye Training and Research Hospital, Clinic of Infectious Diseases and Clinical Microbiology, Istanbul, Turkey 5 University of Health Sciences Turkey, Ankara Training and Research Hospital, Clinic of Infectious Diseases and Clinical Microbiology, Ankara, Turkey 6University of Health Sciences Turkey, Haydarpaşa Numune Training and Research Hospital, Department of Infectious Diseases and Clinical Microbiology, Istanbul Turkey

7Ordu University Faculty of Medicine, Department of Infectious Diseases and Clinical Microbiology, Ordu, Turkey
\end{abstract}

\begin{abstract}
Objectives: To assess the causes, patient characteristics, clinical follow-up of acute viral hepatitis in adults.

Materials and Methods: This prospective study is conducted in acute viral hepatitis patients from different centers across Turkey. Results: From 8 hospitals in 6 provinces, 75 patients (59 males/79\%) between 20 and 69 years of age (mean age: $34.65 \pm 11.82$ years) with proven viral hepatitis were included into the study. There were $54(72 \%)$ patients with acute hepatitis B virus (HBV), 19 (25\%) with acute hepatitis A virus (HAV), 1 (1.3\%) with acute Epstein-Barr virus, and $1(1.3 \%)$ with acute cytomegalovirus infection. Patients between 23-33 years of age represented that greater majority of the patient group (41.3\%), followed by those between 34 and 43 years of age (20\%). The mean age among acute HAV patients, i.e. $27 \pm 5.7$ years $(20-38 y)$ was significantly $(p<0.001)$ lower than the mean age of $37.6 \pm 12.2$ years ( $20-69$ y) acute HBV group. Of 51 isolated acute HBV patients: 44 (86\%) developed immunity during the follow up [anti-hepatitis B core antibody immunoglobulin G (anti-HBc lgG) and
\end{abstract}

\begin{abstract}
ÖZ
Amaç: Erişkinlerde akut viral hepatitin nedenlerini, hasta özelliklerini ve klinik takibini değerlendirmektir.

Gereç ve Yöntemler: Bu prospektif çalışma, Türkiye genelinde farklı merkezlerden akut viral hepatitli hastalarda yapıımıştır.

Bulgular: Altı ildeki 8 hastaneden, 20-69 yaşları arasında (ortalama yaş: $34,65 \pm 11,82$ ) viral hepatiti kanıtlanmış 75 hasta (59 erkek/\% 79) çalışmaya dahil edildi. Akut hepatit B virüslü (HBV) 54 (\%72), akut hepatit $A$ virüslü (HAV) 19 (\%25), akut Epstein Barr virüslü (EBV) $1(\% 1,3)$ ve akut sitomegalovirüs enfeksiyonlu $1(\% 1,3)$ hasta vardı. Hasta grubunun büyük çoğunluğunu 23-33 yaş arası hastalar $(\% 41,3)$ temsil etmekteydi ve bunu $34-43$ yaş arasındakiler $(\% 20)$ izlemekteydi. Akut HAV hastaları arasındaki ortalama yaş, yani $27 \pm 5,7$ yıl (20-38 yıl), akut HBV grubunun ortalama yaşı 37,6 612,2 yıldan (20-69 yıl) önemli ölçüde ( $p<0,001)$ daha düşüktü. Takip sırasında 51 izole akut HBV hastasının 44'ünde (\%86 bağışıklık gelişti anti-hepatit $\mathrm{B}$ çekirdek antikoru immünoglobulin $\mathrm{G}$ (anti-HBc $\mathrm{lgG}$ ) ve anti-HBs pozitifliği). Izole anti-HBc lgG pozitifliği 4 hastada (\%8) görüldü ve 3
\end{abstract}

Tosun S, Albayrak A, Durmuş G, Çetin Altaş İ, Özel AS, Tülek N, Kadanalı A, Erol S, Altunçekiç Yıldırım A, Ceran N, Dağlı 0̈, 0lut AI. Viral Hepat J. 2021;27:36-41. 


\section{ABSTRACT}

anti-HBs positivity], while isolated anti-HBc lgG positivity persisted in 4 patients $(8 \%)$ and 3 patients (\%6) were considered as chronic HBV infection due to persistence of hepatitis B surface antigen positivity beyond 6 months.

Conclusion: Acute HBV infection remains an important health problem in our country, and horizontal and sexual transmission became the predominant routes of transmission for HBV. Also, acute HAV infection is a prevalent condition in young adults.

Keywords: Acute viral hepatitis, hepatitis A virus, hepatitis B virus
ÖZ

hasta (\%) hepatit B yüzey antijeni pozitifliğinin 6 aydan uzun sürmesi nedeniyle kronik HBV enfeksiyonu olarak kabul edildi.

Sonuç: Akut HBV enfeksiyonu ülkemizde önemli bir sağlık sorunu olmaya devam etmektedir ve yatay ve cinsel yolla bulaşma HBV'nin baskın bulaşma yolları haline gelmiştir. Ayrıca akut HAV enfeksiyonu genç erişkinlerde yaygın bir durumdur.

Anahtar Kelimeler: Akut viral hepatit, hepatit A virüsü, hepatit B virüsü

\section{Introduction}

According to the information provided by the World Health Organization (WHO), there are an estimated 325 million chronic hepatitis [hepatitis B virus (HBV) + hepatitis C virus (HCV)] cases globally in 2015. Again, as reported by the WHO, an estimated 7,134 fatalities due to hepatitis A occurred in 2016, comprising $0.5 \%$ of all deaths associated with viral hepatitis. Annual number deaths due to HBV-related complications is around 900,000 $(1,2,3,4)$. In a review estimating the global morbidity and mortality of acute viral hepatitis, cirrhosis due to viral hepatitis, and hepatocellular carcinoma (HCC) prevalence using global disease burden data, it has been reported that the global number of deaths due to viral hepatitis increased from 0.89 million to 1.45 million between 1990 and 2013, and that while viral hepatitis was the $10^{\text {th }}$ most common cause of death in 1990, it was the $7^{\text {th }}$ most common cause of death in 2013. The authors explained this increase on the basis of an increased number of cases presenting with chronic complications such as hepatic failure, cirrhosis, or HCC, emphasizing the need for more widespread vaccination, effective preventive strategies, and increased access to therapy (5).

Viral hepatitis $A$ and $B$ are the most common type of viral hepatitis in our country. National hepatitis B vaccination program initiated in 1998 to target newborns and at-risk individuals followed by the routine vaccination against hepatitis A again in newborns and at-risk individuals (e.g. healthcare workers, medical trainees, chronic hepatitis patients) have contributed significantly to the reduced number of hepatitis due to these two viral agents. Other cases of primary viral hepatitis due to hepatitis $C$, hepatitis $D$, hepatitis E, Epstein-Barr, herpes simplex, varicella-zoster, enterovirus, adenovirus, and measles-mumps-rubella viruses are less frequent. Updated national epidemiological data is important for reducing the burden associated with viral hepatitis.

This multi-center, prospective study conducted across different sites in our country over a one-year period aimed at assessing the causes of acute viral hepatitis, patient characteristics, and prognosis in an adult cohort.

\section{Materials and Methods}

This multi-center study was conducted at 8 hospitals in 6 provinces between 1 May 2016 and 30 June 2017 after ethics committee approval by the Local Ethics Committee, University of Health Sciences Turkey, Izmir Bozyaka Training and Research
Hospital (approval number: 1, date: 09.02.2016). Informed consent forms were obtained from all patients included in the study. Patients over 18 years of age presenting with clinical signs and symptoms of acute hepatitis were included. Sociodemographic data, complaints at presentation, clinical signs, laboratory results, potential routes of transmission, clinical course, treatments administered, complications, prognosis, and follow-up results after discharge were recorded. All patients were prospectively followed weekly during the $1^{\text {st }}$ month, and then HBV patients were asked to attend follow-up visits at 3, 6, and 12 months post-discharge. The following routine tests were performed in patients with symptoms and signs suggestive of acute viral hepatitis: complete blood count, serum alanine aminotransferase (ALT), aspartate aminotransferase (AST), $\gamma$-glutamyl transferase (GGT), total and indirect bilirubin, international normalized ratio (INR), abdominal ultrasound, anti-HAV $\lg \mathrm{M}$ and $\operatorname{lgG}$, hepatitis B surface antigen $(\mathrm{HBsAg})$, anti-HBc IgM [in those with $\mathrm{HBsAg}$ positivity, also anti-HBc $\operatorname{lgG}$, hepatitis $\mathrm{B}$ e antigen ( $\mathrm{HBeAg})$, anti-HBe, HBV-DNA, delta antigen and antibody], toxoplasma IgM and $\mathrm{G}$, cytomegalovirus (CMV) IgM and G, EBV virus capsid antigen (VCA) IgM and G, anti-hepatitis E virus (HEV) $\operatorname{lgM}$ and $\mathrm{G}$ were tested for diagnostic purposes.

\section{Statistical Analysis}

Statistical analyses were performed with JAMOVI (Version 1.1.5.0) software for Windows. Descriptive data were expressed as number and percentage ( $\mathrm{n}$ and \%) for categorical variables, and mean, standard deviation, minimum, and maximum for numerical variables. Comparison of categorical data for independent groups was done with chi-square test. The distribution of the numerical data was evaluated using Kolmogorov-Smirnov test. For independent groups, the numerical data were compared with Student's t-test and Repeated Measures Variance Analysis. Data without normal distribution were assessed with Mann-Whitney $U$ test, Kruskal-Wallis test, non-parametric Friedman's test, and Wilcoxon test. The statistical alpha level of significance was set at a $p$ value of $<0.05$.

\section{Results}

A total of 75 patients (69 males/92\%) between 20 and 69 years of age (mean age: $34.65 \pm 11.8$ years) with proven viral hepatitis were included. There were 19 patients (25\%) with acute HAV, 54 (72\%) with acute HBV, one (1.3\%) with acute EBV, and one (1.3\%) acute CMV infection. No cases of HCV, HEV or toxoplasma were identified. 
Patients between 23-33 years of age represented that greater majority of the patient group (41.3\%), followed by those between 34 and 43 years of age (20\%), 44 and 53 years of age (18.7\%), and 20 and 22 years of age (16\%). However, there was a significant age difference when the specific types of hepatitis were taken into consideration. Thus, most of the patients with acute HAV infection were between 23 and 33 years of age (47.3\%), mostly between 20 and 22 years of age $(42 \%)$ and there were no patients in $>44$ age groups. Most cases of acute HBV infection were between 23 and 33 years of age (39\%), followed by those between $44-53$ years of age (26\%), 34-43 years of age $(22 \%), 20-22$ years of age $(7.4 \%)$, and those above 64 years of age (5.6\%). The mean age among acute HAV patients, i.e. $27 \pm 5.7$ years $(20$ $38 \mathrm{y})$ was significantly $(\mathrm{p}<0.001)$ lower as compared to the mean age of $37.6 \pm 12.2$ years (20-69 y) in acute HBV group (Table 1).

A socio-demographic data analysis was also made in this study.

There were 47 (62.7\%) white-collar and 22 (29.3\%) bluecollar employees in the study group, whereas 6 (8\%) were unemployed. With regard to education, there were $5(6.7 \%)$ illiterate individuals, 16 (21.3\%) primary school graduates, 39 (52\%) secondary school graduates, and 15 (20\%) university graduates. Although no statistical association between educational status and the type of hepatitis could be detected, there was a trend toward higher educational level among acute HAV cases than acute HBV cases (proportion of just literate-illiterate, primary school, secondary school, and university degree among acute HAV cases: 5.2\%, $15.7 \%, 52.6 \%$, and $26.3 \%$, respectively; the corresponding figures in HBV group were $7.4 \%, 24 \%, 51.8 \%$, and $16.7 \%$, respectively). No associations were observed between occupational category and the type of hepatitis $(p=0.255)$, although there were more bluecollar workers in the acute HBV group.

Only three patients (two with acute HBV, and one with EBV) were treated as outpatients and 72 as (96\%) inpatients. The median duration of hospital stay was $13.5 \pm 8$ days (4-21 days). Most patients presented within 3 to 7 days of the onset of symptoms. Underlying/comorbid conditions included malignancy (lung cancer) in 1, diabetes mellitus in 3, Down's syndrome in 1, chronic renal failure in 1, epilepsy in 2, and gall bladder stones in 1 . One male patient admitted with acute HBV + human immunodeficiency virus (HIV) infection, two male patients admitted with primary syphilis + acute HBV infection.

Possible routes of transmission could be detected in 10 of the 19 (52.6\%) acute HAV patients (suspected beverage/food consumption in 9, domestic travel history in another). Among HBV patients, possible risk factors could be detected in 23 (42.9\%), including presence of chronic HBV infection in household members in 3 and in close family members in 2, penetrating injury in 2 (blood sugar measurement with lancet in a patient with chronic hepatitis B infection), and contact with blood or body fluids in 15. No risk factors could be found in 31 (57.4\%) of the acute HBV cases. In three acute HBV cases with suspicious history of sexual intercourse, two had $1^{\text {st }}$ stage syphilis, and one had acute retroviral syndrome.

There were no significant seasonal differences in the distribution of acute HAV patients (spring 3, summer 6, autumn 4, winter 5), while there were more acute HBV cases during autumn and winter (spring 9, summer 13, autumn 18, winter 16).

The most common symptom at presentation was malaise (88\%) followed by urine darkening (80\%), apetite loss $(78 \%)$ jaundice and nausea (77\%). Symptoms were given at Table 2.

The most common clinical examination findings included the following: icteric course in 51 patients (68.1\%; $12 \mathrm{HAV}, 38 \mathrm{HBV}$, $1 \mathrm{CMV}$ ), anicteric course without scleral jaundice in 13 patients (17.3\%; $4 \mathrm{HAV}, 8 \mathrm{HBV}$, and $1 \mathrm{EBV})$, sub-icteric course in 11 patients (14.6\%; $3 \mathrm{HAV}, 8 \mathrm{HBV}$ ), fever in 13 patients (17.3\%), hepatomegaly in 14 patients (18.7\%; HAV 4), splenomegaly in 2 (2.7\%, HBV), hepatosplenomegaly in 7 patients $(9.3 \%$, one HAV).

Laboratory findings were as follows at day 0; among acute HAV patients, mean ALT: 2,177 IU/mL, AST: 1,398, GGT: 242, total bilirubin: 8.84, INR: 1,24, white blood cell (WBC): 6,920, platelet count: 221,000. The corresponding values in acute HBV patients were as follows: ALT: 1,967 IU/mL, AST: 1,431, GGT: 216, total bilirubin: 8.24; INR: 1,2; WBC: 7,590, platelet count: 236,220 (Figure 1, 2).

Mean ALT values were significantly different between acute HAV and acute HBV hepatitis patients, with a more rapid regression in ALT in acute HAV patients ( $p=0.002, p<0.005-F=6.32)$. When the decline in mean AST during the first 7 day period was evaluated, a significantly more rapid decline was found in acute HAV patients as compared to acute HBV patients $(p<0.001)$. However, the decline in AST from day 7 to day 14 did not differ significantly between HAV and HBV patients (for HAV $p=0.05$, for HBV $p>0.05$. On the other hand, the rate of decrease in AST levels after day 14 among acute HAV patients was significantly less marked than those with acute HBV $(p<0.001)$. Again, the rate of decline in mean GGT from day 0 to 7 was also significantly different between acute HAV and acute HBV hepatitis patients. Among acute HAV patients, there was a significantly $(p<0.05)$ more rapid decline of GGT in the first 7-day period as compared to HBV patients, while no significant differences between HAV and HBV patients were observed thereafter ( $p>0.05$ ) (Figure 1, 2).

\begin{tabular}{|l|l|l|l|}
\hline Table 1. Distribution of cases with acute HAV and HBV by age groups & Acute HBV cases & Total* \\
\hline Age groups & Acute HAV cases (n/\%) & $4(7.5 \%)$ & $12(16 \%)$ \\
\hline $20-22$ & $8(42 \%)$ & $21(39 \%)$ & $30(41 \%)$ \\
\hline $23-33$ & $9(\% 47 \%)$ & $12(22 \%)$ & $14(20 \%)$ \\
\hline $34-43$ & $2(\% 11 \%)$ & $14(26 \%)$ & $14(19 \%)$ \\
\hline $44-53$ & 0 & 0 & 0 \\
\hline $54-63$ & 0 & $3(5.6 \%)$ & $3(4 \%)$ \\
\hline$>64$ & 0 & 54 & 73 \\
\hline & 19 & \\
\hline $\begin{array}{l}* * \text { One male patient born in 1990 with acute EBV and one male born in 1979 with acute CMV infection is not included in the table. } \\
\text { HAV: Hepatitis A virus, HBV: Hepatitis B virus, EBV: Epstein Barr virus, CMV: Cytomegalovirus }\end{array}$ \\
\hline
\end{tabular}




\begin{tabular}{|c|c|c|c|c|c|c|}
\hline Complaints at admission & $\operatorname{HAV}(n=19)$ & $\operatorname{HBV}(n=54)$ & $\operatorname{EBV}(n=1)$ & CMV $(n=1)$ & Total $(n=75)$ & $\%$ \\
\hline Weakness & 18 & 46 & 1 & 1 & 66 & 88 \\
\hline Loss of appetite & 16 & 41 & 1 & 1 & 59 & 78.6 \\
\hline Jaundice & 15 & 43 & & & 58 & 77.3 \\
\hline Abdominal pain & 10 & 16 & & 1 & 27 & 36 \\
\hline Muscle pain & 7 & 18 & & 1 & 26 & 34.6 \\
\hline Acholic stool & 11 & 14 & & & 25 & 33.3 \\
\hline Headache & 10 & 11 & 1 & 1 & 23 & 30.6 \\
\hline Dizziness & 5 & 11 & & & 16 & 21.3 \\
\hline Constipation & 3 & 7 & & & 10 & 13.3 \\
\hline Diarrhea & 1 & 4 & & & 5 & 6.6 \\
\hline \multicolumn{7}{|l|}{ Examination findings } \\
\hline Sclera/skin normal & $4(21 \%)$ & $8(15 \%)$ & 1 & & & $9(12 \%)$ \\
\hline Sclera/skin subicteric & $3(15.8 \%)$ & $8(15 \%)$ & & 1 & & $12(16 \%)$ \\
\hline Sclera/skin icteric & $12(63 \%)$ & $38(70.5 \%)$ & & & & $40(53 \%)$ \\
\hline Hepatomegaly & $1(5.3 \%)$ & $10(18.5 \%)$ & & & & $11(15 \%)$ \\
\hline Splenomegaly & 0 & $2(3.7 \%)$ & & & & $2(2.7 \%)$ \\
\hline
\end{tabular}

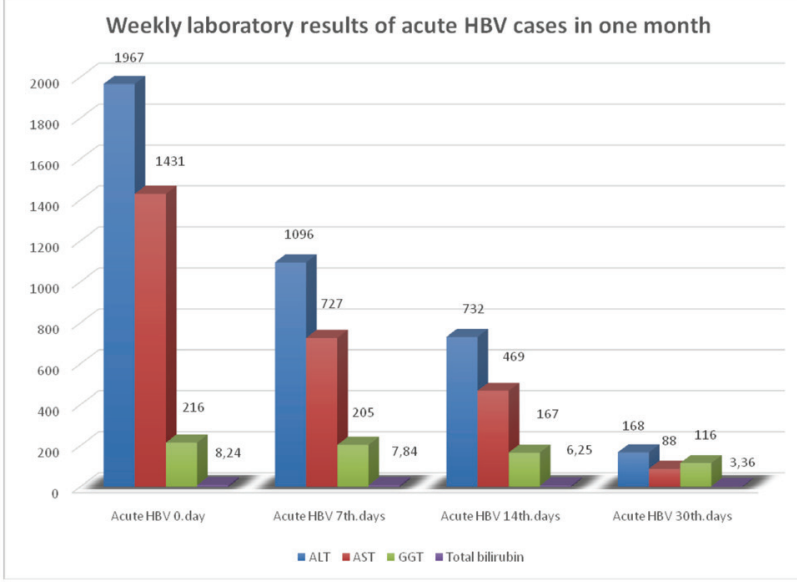

Figure 1. Weekly laboratory results of acute HBV cases in one month HAV: Hepatitis B virus

With regard to prognostic indicators, 2 of the 19 acute HAV patients developed cholestasis, which resolved rapidly. All acute HAV patients improved during the follow-up period, with normalization of laboratory values with a maximum delay of 2 months.

Of 51 isolated acute HBV patients, 44 (86\%) developed immunity during the follow up (anti-HBc lgG and anti-HBs positivity), while isolated anti-HBc $\lg$ positivity persisted in 4 patients (8\%),

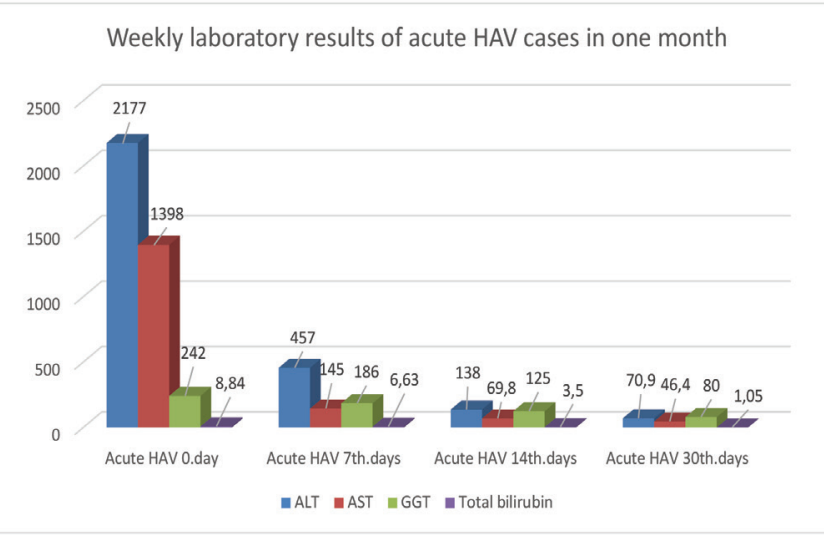

Figure 2. Weekly laboratory results of acute HAV cases in one month HAV: Hepatitis B virus

with no anti-HBs and 3 patients (6\%) were considered as chronic HBV infection due to persistence of HBsAg positivity beyond 6 months. One patient with HBV + HIV co-infection was referred to a liver transplant center, but the patient died before transplantation.

\section{Discussion}

According to the 1994 National Viral Hepatitis Report from Turkey, there were 27,474 reports of adult acute viral hepatitis in 
1,989, and 19,518 in 1,992, most of which were due to acute HBV, followed by acute HAV infection (6). In our study group of 75 adult patients with proven viral hepatitis, most of the cases were due to (72\%) acute HBV infection followed by acute HAV infection (25\%). In a comprehensive review of epidemiological analysis of viral hepatitis in Turkey, most cases of acute HAV occurred in children, and HBV in adults, during the period between 1985 and 2000 (7). Again, in a recent 2018 review on hepatitis B etiology in Turkey, it was emphasized that although there were acute HBV reports in infants between 1996-2000, no acute HBV was reported in that age group after year 2005, with very low rates in children aged 1 to 4 years with a subsequent increase among those aged 15-19 years, reaching a peak in 30-44 years, followed in frequency by those aged 20-29 years, 45-64 years, and >65 years (8). As explained in both reviews, the most common etiological factor for acute hepatitis among adults was HBV, followed by HAV, a special emphasis was made on the fact that there was a striking decrease in acute HBV incidence in children and adolescents in close association with the national HBV vaccination program (8). In another 2011 review looking at the causes of acute hepatic failure in children and adults in Turkey, a total of 308 patients were analyzed between the ages of 1 month and 75 years from 41 studies conducted between 1998 and 2010. In that review, HAV was the most common (20.9\%) cause of acute hepatic failure in children, while it was HBV (34.7\%) in adults. The mean age of the 98 adult patients with acute hepatic failure was 36 years (17-75 y), and $68 \%$ of the patients were female. A total of 39 etiological agents were identified, 34 of which were HBV, 4 were HAV, and one was CMV hepatitis (9).

Over the recent years, some studies examining the etiology of acute hepatitis in adult patients both HAV and HBV infections were more common among males $(10,11,12,13,14,15,16,17)$. In line with these observations, males comprised the great majority of the cases in our study ( $n=59,79 \%)$, with 48 acute HBV and 11 acute HAV infection.

While in some studies an association between the type of hepatitis and seasons was reported, with more common occurrence of these infections during autumn or winter, no such associations were observed in some others. In the current study, although there was no significant seasonality in acute HAV infections, there were more patients diagnosed with acute HBV infection during autumn and winter months. This might reflect the small number of acute HAV patients included. Despite no significant association between the type of hepatitis and sociodemographic data was observed, patients with acute HAV infection tended to have higher educational level, patients with acute HBV were more likely to be blue-collar workers in our study.

The presenting symptoms in our patient group were consistent with literature reports. The most common of these were malaise, dark urine, jaundice, loss of appetite, nausea, and vomiting, with other symptoms being less frequent. While $68.1 \%$ of the patients reported jaundice, anicteric disease course was detected in $17.3 \%$, and sub-icteric in $14.6 \%$ during the physical examination.

In many previous studies possible routes of transmission for these conditions could be poorly defined, with only a minority of studies reporting clear-cut results. In the present study, possible risk factors could be identified in near half of the patients either with acute HAV or acute HBV infection. Since all previously published studies from our country are of retrospective nature, this is not an unsurprising finding. We believe that the prospective design of our study may at least partially explain the higher rates of detection for possible routes of transmission.

The reported prognosis and complications in patients with acute viral hepatitis show little variation between studies. Cholestasis has been relatively more frequently reported in previous studies of acute HAV patients in Turkey; again fulminant disease course and acute hepatic failure were relatively more frequent among acute HBV patients, who also had a higher mortality. Although 2 of the 19 cases with acute HAV infection in our study developed cholestasis, these resolved rapidly with complete recovery during the follow up in both cases.

In 44 (86\%) of the acute HBV patients, immunity developed during the follow-up period (anti-HBc lgG and anti-HBs positivity), 3 patients $(6 \%)$ were considered as chronic HBV infection due to persistence of HBsAg positivity beyond 6 months. Isolated anti$\mathrm{HBc}$ IgG positivity persisted in 4 (8\%) others with no emergence of anti-HBs positivity. At 2 years of follow-up, both patients remained positive for isolated anti-HBc lgG with no anti-HBs. Two cases of acute HBV infection also had $1^{\text {st }}$ stage syphilitic disease, which was treated. One patient with acute HBV infection had concomitant acute retroviral syndrome, was referred to a hepatic transplantation center, but died due to fulminant hepatic failure before transplantation. When the medical records of this patient was retrospectively evaluated, he was found to have negative serology for HBV and HIV.

Obviously, vaccination is indispensable for diseases against which immunization can confer protection. Using the national surveillance data between 1990 and 2012, the most dramatic decline in reported rates of HBV in Turkey was observed in adolescents and children $\leq 15$ years of age, as a result of the nationwide implementation of three doses of HBV vaccination and catch-up vaccination strategy (18). Finally, the "Turkish Viral Hepatitis Prevention and Control Program 2018-2023" initiated by the Ministry of Health in 2018 clearly underscores the importance of surveillance and vaccination, with a 5-year target of reduction in the number of cases with hepatitis (19).

\section{Study Limitations}

As collected in one-year period, number of acute viral hepatitis patients (i.e.: 75) may be low. But we believe that the data provided herein may shed some light on the current status of acute viral hepatitis in Turkey.

\section{Conclusion}

In contrast with many studies with a retrospective design, this up-to-date prospective study showed that acute HBV infection remains an important health problem in our country, and that horizontal and sexual transmission became the predominant routes of transmission for $\mathrm{HBV}$, due to the fact that vaccination has conferred immunity to most children and adolescents in recent years. Also, acute HAV infection is a prevalent condition in young adults, and it appears that it will remain so, until children vaccinated in the context of the national vaccination program reach adulthood in a decade or so. 


\section{Ethics}

Ethics Committee Approval: This multi-center study was conducted at 8 hospitals in 6 provinces between 1 May 2016 and 30 June 2017 after ethics committee approval by the Local Ethics Committee, University of Health Sciences Turkey, Izmir Bozyaka Training and Research Hospital (approval number: 1, date: 09.02.2016).

Informed Consent: Informed consent forms were obtained from all patients included in the study.

Peer-review: Externally and internally peer-reviewed.

\section{Authorship Contributions}

Concept: S.T., A.A., G.D., I.Ç.A., A.S.Ö., N.T., A.K., S.E., A.A.Y., N.C., Desing: S.T., A.A., G.D., I.Ç.A., A.S.Ö., N.T., A.K., S.E., A.A.Y., N.C., Materials: S.T., A.A., G.D., I.Ç.A., A.S.Ö., N.T., A.K., S.E., A.A.Y., N.C., Data Collection or Processing: Ö.D., A.I.O., Analysis or Interpretation: Ö.D., A.I.O., Literature Search: Ö.D., A.I.O., Writing: Ö.D., A.I.O.

Conflict of Interest: No conflict of interest was declared by the authors.

Financial Disclosure: The financial support of the study was provided by the researchers.

\section{References}

1. WHO Hepatitis (Access date: 10.05.2020) https://www.who.int/ csr/disease/hepatitis/en/

2. Global Health Sector Strategy on viral hepatitis 2016-2021, WHO 2016 (Access date10 May 2020) https://apps.who.int/ iris/bitstream/handle/10665/246177/WHO-HIV-2016.06-eng. pdf? sequence $=1$

3. Global Hepatitis Report, 2017. World Health Organization https://apps.who.int/iris/bitstream/ h a nd le / $10665 / 255016 / 9789241565455$ eng. pdf? sequence $=1$ \&isAllowed $=\mathrm{y}$

4. Stravitz RT, Lee WM. Acute liver failure. Lancet. 2019;394:869.

5. Stanaway JD, Flaxman AD, Naghavi M, Fitzmaurice $C$, Vos T, Abubakar I, Abu-Raddad LJ, Assadi R, Bhala N, Cowie B, Forouzanfour $\mathrm{MH}$, Groeger J, Hanafiah $\mathrm{KM}$, Jacobsen $\mathrm{KH}$, James SL, MacLachlan J, Malekzadeh R, Martin NK, Mokdad AA, Mokdad AH, Murray CJL, Plass D, Rana S, Rein DB, Richardus JH, Sanabria J, Saylan M, Shahraz S, So S, Vlassov VV, Weiderpass E, Wiersma ST, Younis M, Yu C, El Sayed Zaki M, Cooke GS. The global burden of viral hepatitis from 1990 to 2013 findings from the Global Burden of Disease Study 2013. Lancet. 2016;388:1081-1088
6. Badur S. Ülkemizde viral hepatitlerin durumu (). In: Kılıçturgay K, editor. Viral Hepatit 94. Istanbul, Viral Hepatitle Savaşım Derneği Raporu, Nobel Tıp Kitabevleri; 1994; pp. 15-37.

7. Mıstık R, Balık I. Türkiye'de viral hepatitlerin epidemiyolojik analizi. In: Kaya Kilıçturgay, Badur S, editors. Viral Hepatit 2001. Istanbul: Viral Hepatitle Savaşım Derneği; 2001; pp. 9-55.

8. Tosun S. Dünya'da ve Türkiye'de viral hepatit B Epidemiyolojisi. In: Rahmet Güner, Tabak F, editors. Viral Hepatit 2018. Istanbul: Istanbul Medikal Sağlık ve Yayıncılık; 2018; pp. 13-48.

9. Kayaalp C, Ersan V, YIlmaz S. Acute liver failure in Turkey: A systematic review. Turk J Gastroenterol 2014;25:35-40.

10. Öztüfekçi $A$, Mıstık R, Heper $Y$, et al. Kliniğimizde izlediğimiz akut viral hepatit $A^{\prime}$ 'ı olgularımızın bazı klinik ve laboratuar özellikleri. Proceedings of the VI. Ulusal Viral Hepatit Sempozyumu 202031 October-2 November, Ankara, Turkey; 2020; pp. 37.

11. Kandemir B, Bitirgen M, Arıbaş ET. Selçuk üniversitesi Meram Tıp Fakültesi Klinik Bakteriyoloji ve Infeksiyon Hastalıkları Kliniği'nde 1990-2004 yılları arasında yatırılarak izlenen akut viral hepatit olgularının değerlendirilmesi. Selçuk Tıp Dergisi. 2007;23:77-83.

12. Yamazhan $T$, Arda B, Tuncel $M$, et al. Akut hepatitli olgularımızın değerlendirilmesi. Retrospektif bir inceleme. Viral Hepatit J. 2001;2:294-297.

13. Öncü $S$, Ertuğrul B, Çağatay $A$, Eraksoy H, Özsüt $H$, Çalangı $S$. Does The Epidemiology Of Acute Viral Hepatitis Change In Adult Patients? Viral Hepatit J. 2002;8:514-517.

14. Çolpan $A$, Bodur $H$, Erbay $A$, et al. Akut viral hepatit olgularının değerlendirilmesi. Viral Hepatit J. 2003;8:20-24

15. Ak Ö, Sarı H, Gençer S, Benzonana N, Yıldııım N, Özer S. Akut hepatit B olgularımızın klinik ve laboratuvar özellikleri. Proceedings of the VII. Ulusal Viral Hepatit Kongresi 2004 24-28 November, Ankara, Turkey; 2020; pp. 12.

16. Türker $T$, Babayiğit MA, Tekbaș ÖF, Oğur R, Avcı IY, Pahsa A, Hasde M. Frequency and distribution of hospitalizations due to viral hepatitis at Gulhane Military Medical Academy between 2002 and 2004. Gülhane Tıp Dergisi. 2006;48:125-131.

17. Koruk ST, Gürsoy B, Koruk I, Yıldı Zeyrek F, et al. Evaluation of Cases with Acute Viral Hepatitis. Viral Hepatit J. 2006;11:132-137.

18. Ay P, Torunoglu MA, Com S, Çipil Z, Mollahaliloğlu S, Erkoc Y, Dilmen U. Trends of hepatitis B notification rates in Turkey, 1990 to 2012. Euro Surveill. 2013;18: 20636

19. Türkiye Viral Hepatit Önleme Ve Kontrol Programı (2018-2023) https://hsgm.saglik.gov.tr/depo/birimler/Bulasici-hastaliklar db/ duyurular/Turkiye_Viral_Hepatit_Onleme_ve_Kontrol_Programi/ Turkiye_Viral_Hepatit_Onleme_ve_Kontrol_Programi_TR.pdf 